\title{
The limits of the body: boundaries, capacities, thresholds
}

\section{Sebastian Abrahamsson \& Paul Simpson}

To cite this article: Sebastian Abrahamsson \& Paul Simpson (2011) The limits of the body: boundaries, capacities, thresholds, Social \& Cultural Geography, 12:04, 331-338, DOI: 10.1080/14649365.2011.579696

To link to this article: https://doi.org/10.1080/14649365.2011.579696

\section{Published online: 16 May 2011.}

Submit your article to this journal $\square$

Џll Article views: 1726

Q View related articles ๘

4 Citing articles: 39 View citing articles 진 


\title{
Editorial
}

\section{The limits of the body: boundaries, capacities, thresholds}

\author{
Sebastian Abrahamsson ${ }^{1} \&$ Paul Simpson ${ }^{2}$ \\ ${ }^{1}$ Amsterdam Institute for Social Science Research, University of Amsterdam, Kloveniersburgwal \\ 48, Amsterdam 1012 CX, The Netherlands and ${ }^{2}$ School of Geography, Earth and Environmental \\ Sciences, University of Plymouth, Drake Circus, Plymouth PL4 8AA, UK, \\ paul.simpson@plymouth.ac.uk
}

\section{Introduction}

Where does one body end and another one begin? Is the limit of a body drawn at the skin, or does a body extend beyond its epidermis? If we both are and have a body then where does it/I end? Strange questions perhaps, although we are not the first ones to ask them. Think about the child whose sense of a delimited body is yet not fully developed. Or about the blind person, evoked by Bateson (2000), and the stick or prosthetic with which he or she navigates his or her world. Such bodies, while limited in Euclidean space also extend beyond themselves. The peculiar phantom limb phenomenon is exemplary here. Conversely, think about the limits that are imposed on bodies: imprisoned bodies, amputated bodies, bodies that are slowed down or held still. The child will learn that there are limits to what one can do; the blind person will sooner or later hit upon a wall with his or her stick; and the phantom in the non-existing limb can be exorcised. The limits of the body are redrawn and delimited. Where and how-by which modes of representation, by which technologies and apparatuses, which strategies and practices-are those limits drawn, modified and performed? These are the questions that the papers in this special issue address in one way or another.

In addressing these questions, these papers further contribute to the prominent place discussions of the body and embodiment have been granted in recent work in social and cultural geography (for a range of examples, see Abrahamsson 2010; Bissell 2009; Colls 2004; Evers 2009; Gokariksel 2009; Jones 2005; Longhurst 2001; Middleton 2010; Obrador-Pons 2007; Nast and Pile 1998; Simpson 2008; Straughan 2010). In an attempt to attend to the illusory nature of the body (Dewsbury 2000), there has been a move to make "the body the very "stuff" of 
subjectivity' (Grosz 1994: ix). For example, the body has been examined as a site of creativity and experimentation (McCormack 2002); as that which because of its hybridity is always already more-than-human (Whatmore 2006); as an embodied social/cultural/ gendered site of production and inscription (Longhurst 1997); as vulnerable, susceptible, and exposed (Harrison 2008); and as that which not only inhabits but also produces space (Thrift 2000, 2007). Extending theoretical and empirical insights from relational philosophies and post-structuralism, this work explores how the body can never be understood as an essence or as a self-contained entity, independent of an outside with which the body is relationally constituted.

As such, for geographers, the body becomes a matter of concern because of the ways in which it is relationally coupled with space and time: it is what constantly changes and still endures; it is part of what we have and part of what we are; it is worked upon from an outside and worked with from an inside; it is done in scientific and everyday practices; it is constituted by socio-cultural inscriptions and by evolutionary-neuronal forces. These dialectics should all be rather familiar. The questions one could pose then, tentatively, are how to go on, and where one might go from here?

The response pursued in this themed issue relates to an examination of something that all too often remains implicit within such discussions of the body-the notion of its limits. While the title of this themed issue and its reference to 'the limits of the body' might suggest a dissatisfaction with the body as an empirical or conceptual focus for research in social and cultural geography-understood as the limits and limitations of research on and with the body - this could not be further from the case here. Rather, what we seek to do here is approach the now widely accepted relationality present in discussions of the body in a more delimited and so nuanced way (Harrison 2007). The various papers collected here show how thinking of this relationality in terms of limits (variously conceived) can allow us to come to a more singular understanding of the socio-spatial and materially constituted nature of the body. In this sense, this special issue wishes to expand the ways in which the relationality of the body has been conceived in social and cultural geography by exploring how the limits of the body are done in practice, empirically.

In this latter sense, a limit can be understood as that which separates inside from outside; as a skin or a membrane that separates organism from environment; as a boundary between categories (see Longhurst 2001). Equally though, and taking this further, a limit can also be understood as something to be pushed and/or reached beyond; as a maximum or minimum capacity to act; or, as the threshold beyond which one can never reach. The limit, then, is highly significant to our understanding of what a body could be and its inhabitation of space. Uncovering, experiencing, or experimenting with what, where and when the limits of the body are, when taken in the senses suggested above as a specific lens into thinking relationality that focuses on boundaries but also thresholds and the like, can make evident or potentially disrupt our notion of what it means to be a human being in the world (Olsson 1991).

The papers that make up this themed issue emerge from a series of sessions organized at the Association of American Geographers Annual Conference in Las Vegas in 2009 around the theme: 'The Limits of the Body'. In the call for papers for those sessions we deliberately left the specific understanding of limits quite open. We suggested it in broad 
terms: as biological, phenomenological, psychological, social, material, and so on. So as to make what we mean here more evident and draw out the contributions we see the papers in this issue making to this theme, in this introduction we would like to outline four possible understandings of the limits of the body. These are by no means exhaustive, but in various ways speak to the papers and their engagement with this theme.

\section{Limit as temporal}

The first understanding of the limit we would like to suggest relates to the body's finitude. Nancy (2004: 45) suggests that 'the limit is the end: the extremity beyond which there is nothing-nothing more, at least, of the thing or being of which one reaches the limit'. The body, then, has temporal limits-it is a vulnerable, fleshy, decomposable substance. Bodies become ill, they deteriorate, they die. The limit places an end, imposes an end. However, we should also note that, "[n]o process said to be "natural" or "technical" can be led to a completion that would not be as well interruption ... its unaccomplishment is therefore as well its accomplishment, but an accomplishment without end' (Nancy 2004: 45). In this sense, one never reaches the limit of the body, one can never experience its finitude, our own death. Rather, one is always exposed to it and does not cease coming up against it.

This sense of the limit as a finitude we do not cease to come up against comes to the fore in Maria Fannin's contribution to this special issue in her discussion of personal stem cell banking and specifically the banking of umbilical cord blood and endometrial tissue. In particular, Maria's paper focuses on the ways that stem cell banking has emerged in response to potential future treatments geared toward using the regenerative capacities of stem cells in the repair of damaged or diseased cells. This constitutes a future potential to overcome the body's finitude and temporal limits, or what Maria calls the immaterial imaginaries of extending life beyond its biological limits and of transforming each bodily limit into a frontier to be overcome'. Such banking then acts as a form of risk-management, or what Maria terms 'bio-insurance', against such physiological limitations and so for the preservation of 'future life' (both of the individual and their relatives) and as such an attempted deferral of our inevitable, yet ultimately unexperienceable, encountering of the limit of our corporeal being-in-the-world. As such it resonates with the biopolitical, and burgeoning attempts to extend 'life' beyond the temporal limits of the living through, for example, cryogenics (cf. Doyle 2003). But it is at the same time different from the latter in that the bodily limits that Maria's paper evoke are also spatial; umbilical cord blood banking also constitutes a spatial displacement through which the body, or parts thereof, is made to subsist outside the boundaries of the skin.

\section{Limit as spatial}

This leads us to the second sense of the limits of the body we would like to suggest. In this discussion of the temporal limits of the body, Maria raises an inherent tension within such treatments in terms of property and when a body is properly whole and to whom bodily matter legally belongs once such material has been removed from the bounded limits of a body and stored elsewhere in a tissue bank for potential future use. Building on recent work in geography interested in the politics of bodily matter and its mobility (see Boyer 
2009; Davies 2006), her paper raises interesting questions for geographers to consider in terms of the spatial limits placed on a body for it to maintain a 'proper' unity. This theme has emerged across a range of work in social and cultural geography, particularly in light of recent re-engagments with phenomenology and the late writings of Merleau-Ponty (see Allen 2004; Sheller 2007; Wylie 2002, 2005 ). This work has sought to soften the intentional subject of traditional phenomenological thought and rather make the body-subject 'of' the world, enfolded with it and emergent from this mutual co-implication (Wylie 2006). Here the point at which the limits of the body come into contact with the world are lost in the folds of a common element from which both devolve, making it difficult to see where one ends and the other begins or draw any clear distinction between that which belongs to the body and that which belongs to the world.

This spatiality of the body and its limits is evoked in another sense in Matt Wilson's contribution to this themed issue. Discussing how the bodies and eyes of participants were trained to discern and map geographic data as part of the work of a nonprofit organization in Seattle, Matt shows how citizens were trained to become geocoding subjects; subjects that have a particular capacity for becoming aware of and paying attention to the environments through which they move (also see Martin 2010). Such training draws attention to the ways in which the perceptual capacities and limits of the body's sense organs can be trained and/or expanded upon, meaning what is visible to us, and more generally sensible for us, is not the sum of the world's spatial reality. As such, Matt's question 'how do bodies map and what are the limits to recognizing mapped bodies?' probes a limit that is both spatial and perceptual.
This in turn connects to a further spatiality of the limit in terms of the liminal. In particular, we can understand the liminal as a sort of betwixt and between spatiality, a spacing where that which is deemed 'proper' is suspended and where the potential for the unforeseen to emerge comes into view. In his discussion of this neighbourhood mapping, Matt draws attention to the ways in which such practices can act to bring certain bodies-here mundane things like shopping carts-into visibility and in so doing mark the limit at which such visibility occurs, defining a threshold to be crossed. Equally though, this also places some bodies in a liminal space, a space in which they are not visible or cannot come to visibility, dependent upon the subjectification processes such 'geocoding subjects' go through.

\section{Limit as capacity}

Thirdly, another possible way to consider the limits of the body connects to recent discussions in the geographies of affect and attempts to develop an understanding of limits in terms of thinking about what a body can do (Anderson 2005; Anderson and Harrison 2006; Bissell 2008; Brown 2008; McCormack 2003; Simpson 2011; Thrift 2007). A key point of reference in these discussions have been the writings of Deleuze and Guattari who argue that 'we know nothing about a body until we know what it can do, in other words what its affects are, how they can or cannot enter into composition with other affects, with the affects of another body' (2004: 284). This cannot be known in advance-we cannot define a body by its organs and functions. From this then, we can argue that the limit is highly significant to our understanding of the body in that experiencing the limit, or experimenting with 
what the body's limits are, can make evident, or potentially disrupt, our notion of what it means to be human. Equally important in foregrounding these capacities to affect and become affected here is the way in which the body and its limits become matters for training, therapeutics, and experimentation. The body and its limits become matters for 'empirical experimentation'. In Latour's (2004: 206) words, a body is 'an interface that becomes more and more describable as it learns to be affected by more and more elements'.

In his paper on mixed martial arts (MMA) in this issue, Kyle Green approaches this sense of the limits of the body in discussing what a body can do, or what a body can have done to it, and how this can be pushed, tested and expanded upon in and through practices of MMA training. In particular, and in some ways connecting back to the earlier discussion of bodily finitude, Kyle considers how pain, as a physical experience, becomes a mode of relating to one self and others. It is not until you experience pain, his informants tell him, that you get to know yourself. As Green points out, social science lacks the theoretical and methodological vocabulary for articulating what is at stake in pain. The limits of the body that experiences pain, Green argues, are not only expanded outwards-through the community and intimacy that pain establishes between MMA hobbyists-but, perhaps more importantly, also contract inwards. Put differently, those limits move in both a centrifugal and a centripetal manner. The capacities of the body to affect and be affected can be expansive and limiting.

While Kyle draws out the intensity of such liminal experience, Paul Barratt's contribution to this issue draws attention to how experiences can in fact be dulled. In talking about climbers' use of safety equipment, Paul highlights that while these can expand upon what a climbing body can do by removing certain risks, or importantly fear, in certain activities (see England and Simon 2010; Saville 2008), this can detract from the intensity of such experience. This then reminds us that such intensive experiences and capacities to affect and be affected are always fluctuating and multiple, not something that can be defined in advance or taken for granted. The movement of the limits of the body need not always necessarily be expansive. As Deleuze (1988) emphasizes, the body enters into new compositions which can expand our capacities to act, but there are also compositions which decompose those capacities. There is a relative movement of speed and slowness, composition and decomposition; the limits shift. What a body could once do, it may not be able to do anymore. And just because it can do more now does not mean that such experiences will be felt with greater intensity.

\section{Limits of 'the human'}

Building on this thinking of the limits of the body as a fluctuating capacity, our final suggestion for thinking about the limits of the body appears in light of recent attempts to think about the body in terms of posthumanism. The post-human, according to Hayles (1999: 3), is what we have always already been: 'there are no essential differences or absolute demarcations between bodily existence and computer simulation, cybernetic mechanism and biological organism, robot teleology and human goals'. Here, bodily limits define systems within systems; the body, our 'computational nature' (1999: 279), is always already coupled with other cybernetic and autopoietic devices. Or as Stiegler puts it: 'the prosthesis is not a mere extension of the 
human body; it is the constitution of this body qua "human"' (1998: 152-153).

In geography the figure of the post-human has been taken up by various scholars (see Abrahamsson and Abrahamsson 2007; Dixon and Whitehead 2008). Notably, Whatmore (2004: 1361) talks about the 'more-thanhuman' (rather than the post-human) to designate the 'excess' of humanism/the human, thus evoking 'a different kind of historicity’. Similarly, Braun (2004: 272) argues against the historicism of the post in the post-human, configured as a temporal rupture and break with the human. He advocates a view of the post-human as ontology wherein the "human body is not, never was, and never can be, simply "itself"'. There is thus a tension within this figure of the post-human of the complete evaporation or 'blurring' of limits, on the one hand, and the affirmation of hybridity and excess that is ontological rather than historical, on the other hand. What matters here is not that 'we are now' for all sorts of reasons 'seeing the proliferation of blurring boundaries', but that the boundary and the limit itself has always been a practical achievement; it serves a purpose, be it socio-cultural, geopolitical, material or bio-evolutionary.

Contributing specifically to this literature then, and returning to Paul's ethnographic work with climbers, his contribution to this issue articulates a variety of ways in which the climbing body is co-produced through the interrelation of climbers' organic bodies and the mundane 'kit' they routinely use (climbing shoes, chalk etc.). Particularly interesting here is the ubiquity of these technologies and the ways in which the limits of the body are unthinkingly extended through such prosthetic enhancements. Echoing Braun (2004), Paul draws attention to how the prosthetic enhancement of the climbing body is less a rupture with an understanding of what the human is and more of interest in terms of how such enhancement serves a practical purpose in building upon the body's capacity to act. Equally, we can see this in Matt's paper and his consideration of the 'cyborg vision' produced in and through the training of the geocoding subjects, or in Maria's paper and the technoenhanced future modifications that the cells bank may potentially offer. Ultimately then, it is not a case of getting beyond the human, but rather that in practice the limits of the body are always already blurred and moving in and out of focus.

\section{Openings}

To conclude then, it is important that the papers collected here are taken as an opening rather than the final word. There are of course many other ways to approach the limits of the body as a specific form of relationality than those mentioned above and in the papers that follow. We will limit ourselves to two examples, drawn from our own work. One situation, for instance, where boundaries and limits between the body of the world and human bodies could be probed is through practices of eating. Something very mundane, like eating an apple, puts many limits and boundaries at stake, not only those between environment and body, but also those between self and other, resource and waste (see $\mathrm{Mol}$ 2008). Related to this, nascent work in geography considering materiality beyond the realms of the solid has opened up questions about the boundedness of the body. Given we take in other matter simply by the simple fact of breathing, this asks challenging questions about how easily we can think about the body separate from its environs (see Stewart 2010). Further, another 
consideration could be the inter-corporeal relations that occur between human bodies. If our subjectivties and our bodies are constantly being remodelled and reworked through our relations with the world around us as a range of recent work in geography has argued, it is important to think about the implications this has for how we understand social relations and the tensions at the limit where one body-subject encounters another, the spacing inherent in any such relation, and the dual movement of coming into contact and moving from contact that this presents (see Nancy 2000). We would hope that in light of the papers presented here, these further limits, and others, might be probed by future geographic enquiry.

\section{Acknowledgements}

We would like to thank Michael Brown for comments on this introduction and for his rigorous engagement with the papers that make up this issue. Thanks also go to the authors for their timely work on their papers. Finally, we wish to extend our gratitude to all those who found their way to and presented in the sessions in Las Vegas in 2009 from which this issue emerges.

\section{References}

Abrahamsson, C. and Abrahamsson, S. (2007) In conversation with the body conveniently known as Stelarc, Cultural Geographies 14: 293-308.

Abrahamsson, S. (2010) Stillness, re-animated: experiencing Body Worlds and the work of art, in Bissell, D. and Fuller, G. (eds) Stillness in a Mobile World. London: Routledge, pp. 155-171.

Allen, C. (2004) Merleau-Ponty's phenomenology and the body-in-space encounters of visually impaired children, Environment and Planning D: Society and Space 22: $719-735$.
Anderson, B. (2005) Practices of judgement and domestic geographies of affect, Social \& Cultural Geography 6: 645-659.

Anderson, B. and Harrison, P. (2006) Questioning affect and emotion, Area 38: 333-335.

Bateson, G (2000) Steps to an Ecology of Mind. Chicago: Chicago University Press.

Bissell, D. (2008) Comfortable bodies: sedentary affects, Environment and Planning A 40: 1697-1712.

Bissell, D. (2009) Conceptualising differently-mobile passengers: geographies of everyday encumbrance in the railway station, Social \& Cultural Geography 10: 173-195.

Boyer, K. (2009) Of care and commodities: breast milk and the new politics of mobile biosubstances, Progress in Human Geography 31: 5-20.

Braun, B. (2004) Querying posthumanism, Geoforum 35: 269-273.

Brown, G. (2008) Ceramics, clothing and other bodies: affective geographies of homoerotic cruising encounters, Social \& Cultural Geography 9: 915-932.

Colls, R. (2004) 'Looking alright, feeling alright': emotions, sizing and the geographies of women's experiences of clothing consumption, Social \& Cultural Geography 5: 583-596.

Davies, G. (2006) Patterning the geographies of organ transplantation: corporeality, generosity and justice, Transactions of the Institute of British Geographers 31: 257-271.

Deleuze, G. (1988) Spinoza: Practical Philosophy. San Fransisco: City Lights Books.

Deleuze, G. and Guattari, F. (2004) A Thousand Plateaus: Capitalism and Schizophrenia. London: Continuum.

Dewsbury, J.D. (2000) Performativity and the event: enacting a philosophy of difference, Environment and Planning D: Society and Space 18: 473-496.

Dixon, D.P. and Whitehead, M. (2008) Technological trajectories: old and new dialogues in geography and technology studies, Social \& Cultural Geography 9: 601-611.

Doyle, R. (2003) Wetwares: Experiments in Postvital Living. Minneapolis: University of Minnesota Press.

England, M.R. and Simon, S. (2010) Scary cities: urban geographies of fear, difference and belonging, Social \& Cultural Geography 11: 201-207.

Evers, C. (2009) 'The Point': surfing, geography and a sensual life of men and masculinity on the Gold Coast, Australia, Social \& Cultural Geography 10: 893-908.

Gokariksel, B. (2009) Beyond the officially sacred: religions, secularism and the body in the production of 
subjectivity, Social \& Cultural Geography 10: 657-674.

Grosz, E. (1994) Volatile Bodies: Towards a Corporeal Feminism. Indianapolis: Indiana University Press.

Harrison, P. (2007) 'How shall I say it ... ?' Relating the nonrelational, Environment and Planning A 39: 590-608.

Harrison, P. (2008) Corporeal remains. Vulnerability, proximity and living-on after the end of the world, Environment and Planning A 40: 423-445.

Hayles, K. (1999) How We Became Posthuman: Virtual Bodies in Cybernetics, Literature, and incformatics. Chicago: University of Chicago Press.

Jones, P. (2005) Performing the city: a body and a bicycle take on Birmingham, UK, Social \& Cultural Geography 6: 813-830.

Latour, B. (2004) How to talk about the body? The normative dimension of science studies, Body \& Society 10: 205-229.

Longhurst, R. (1997) (Dis)embodied geographies, Progress in Human Geography 21: 486-501.

Longhurst, P. (2001) Bodies: Exploring Fluid Boundaries. London: Routledge.

Martin, L.L. (2010) Bombs, bodies and biopolitics: securitizing the subject at the airport security checkpoint, Social \& Cultural Geography 11: 17-34.

McCormack, D. (2002) A paper with an interest in rhythm, Geoforum 33: 469-485.

McCormack, D. (2003) An event of geographical ethics in spaces of affect, Transactions of the Institute of British Geographers 28: 488-507.

Middleton, J. (2010) Sense and the city: exploring the embodied geographies of urban walking, Social o Cultural Geography 11: 575-596.

Mol, A.-M. (2008) I eat an apple. On theorizing subjectivities, Subjectivity 22: 28-37.

Nancy, J.-L. (2000) Being Singular Plural. Stanford, CA: Stanford University Press.

Nancy, J.-L. (2004) Banks, edges, limits, Angelaki: Journal of the Theoretical Humanities 9: 41-53.

Nast, H. and Pile, S. (1998) Places Through the Body. London: Routledge.
Obrador-Pons, P. (2007) A haptic geography of the beach: naked bodies, vision and touch, Social \& Cultural Geography 8: 123-141.

Olsson, G. (1991) Lines of Power/Limits of Language. Minneapolis: University of Minnesota Press.

Saville, J.S. (2008) Playing with fear: parkour and the mobility of emotion, Social \& Cultural Geography 9: $891-914$.

Sheller, M. (2007) Bodies, cybercars and the mundane incorporation of automated mobilities, Social \& Cultural Geography 8: 175-197.

Simpson, P. (2008) Chronic everyday life: rhythmanalysing street performance, Social \& Cultural Geography 9: $807-829$.

Simpson, P. (2011) 'So, as you can see...' Some reflections on the utility of video methodologies in the study of embodied practices, Area, Online publication, doi:10.1111/j.1475-4762.2011.00998.x.

Stewart, K. (2010) Atmospheric attunements, Environment and Planning D: Society and Space, Online publication doi:10.1068/d9109.

Stiegler, B. (1998) Technics and Time 1. Stanford, CA: Stanford University Press.

Straughan, E.R. (2010) The salon as clinic: problematising, treating and caring for skin, Social \& Cultural Geography 11: 647-661.

Thrift, N. (2000) Still life in nearly present time: the object of nature, Body \& Society 6: 34-57.

Thrift, N. (2007) Non-representational Theory: Space, Politics, Affect. London: Routledge.

Whatmore, S. (2004) Humanism's excess: some thoughts on the 'post-human/ist' agenda, Environment and Planning A 36: 1360-1363.

Whatmore, S. (2006) Materialist returns: practising culture geography in and for a more-than-human world, Cultural Geographies 13: 600-609.

Wylie, J. (2002) An essay on ascending Glastonbury Tor, Geoforum 33: 441-454.

Wylie, J. (2005) A single day's walking: narrating self and landscape on the South West Coast Path, Transactions of the Institute of British Geographers 30: 234-247.

Wylie, J. (2006) Depths and folds: on landscape and the gazing subject, Environment and Planning D: Society and Space 24: 519-535. 